\title{
SLC6A2 wt Allele
}

National Cancer Institute

\section{Source}

National Cancer Institute. SLC6A2 wt Allele. NCI Thesaurus. Code C117243.

Human SLC6A2 wild-type allele is located in the vicinity of $16 q 12.2$ and is approximately $51 \mathrm{~kb}$ in length. This allele, which encodes sodium-dependent noradrenaline transporter protein, is involved in the transport of norepinephrine into presynaptic cells. Variation of the gene is associated with orthostatic intolerance. 